\title{
HOW FAR DOES THE CAPL TRAVEL? \\ A COMPARATIVE OVERVIEW OF THE CAPL MODEL FORM OPERATING PROCEDURE AND THE AIPN MODEL FORM INTERNATIONAL OPERATING AGREEMENT
}

\author{
MiCHAEL D. JOSEPHSON*
}

The author examines the differences between the Canadian Association of Petroleum Landmen model form Operating Procedure and the Association of International Petroleum Negotiators model form International Operation Agreement and identifies the rationale behind the differing approaches to key aspects of joint operations. He concludes that, while each model form has its place in the specific industry for which it was developed, a workable international joint operating agreement must reflect the types of issues addressed by the latter model form.
L'auteur examine les différences entre la formule normalisée de l'entente exécutoire de la Canadian Association of Petroleum Landmen et celle de la Association of International Petroleum Negotiators pour les opérations conjointes internationales. Il donne aussi le raisonnement des diverses démarches à l'égard des aspects clés de ces opérations. Il conclut que, bien que chaque formule normalisée ait sa place dans le secteur pour lequel elle a été développée, une entente raisonnable relative aux opérations conjointes internationales doit refléter les diverses questions que cette formule couvre.

\section{TABLE OF CONTENTS}

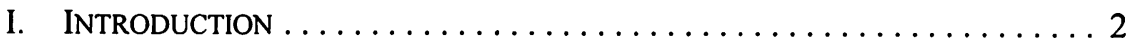

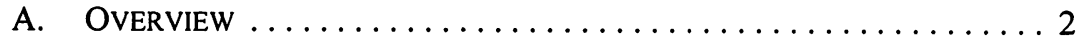

B. Legal Nature of THE GRANT OF PETROLEUM RightS $\ldots \ldots \ldots 4$

C. Production SHARING AgreEMENTS $\ldots \ldots \ldots \ldots \ldots \ldots \ldots 6$

II. STYLE OF THE FORMS $\ldots \ldots \ldots \ldots \ldots \ldots \ldots \ldots \ldots \ldots \ldots \ldots \ldots$

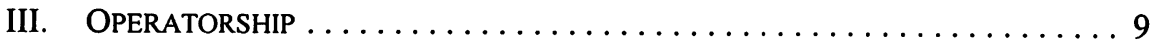

A. APPOINTMENT AND REPLACEMENT OF OPERATOR . . . . . . . . . . . . . 9

B. CONDUCT AND STANDARDS OF OPERATOR $\ldots \ldots \ldots \ldots \ldots \ldots . \ldots$

C. LIMITATIONS ON LIABILITY OF OPERATOR $\ldots \ldots \ldots \ldots \ldots \ldots \ldots$

IV. JOINT OPERATIONS .......................... 12

A. Operating COMmitTeES AND the ROle OF NON-Operators $\ldots \ldots 12$

B. WORK PROGRAMS ANd BUdGETS $\ldots \ldots \ldots \ldots \ldots \ldots \ldots \ldots$

C. AUTHORITY FOR EXPENDITURE $\ldots \ldots \ldots \ldots \ldots \ldots \ldots \ldots \ldots$

D. SUPPLEMENTAL AUTHORIZATIONS FOR EXPENDITURE $\ldots \ldots \ldots \ldots 14$

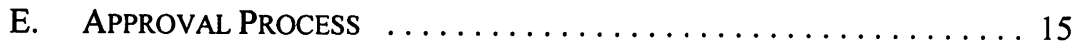

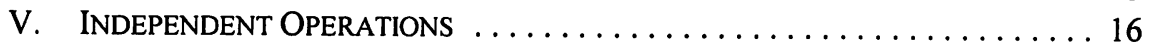

A. Overview . ................................ 16

B. RESTRICTIONS ON INDEPENDENT OPERATIONS $\ldots \ldots \ldots \ldots \ldots \ldots$

C. ReINSTATEMENT AND RELINQUiSHMENT OF RIGHTS $\ldots \ldots \ldots \ldots \ldots 17$

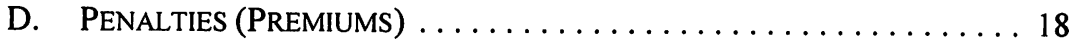

E. OPERATORSHIP OF INDEPENDENT OPERATIONS $\ldots \ldots \ldots \ldots \ldots \ldots$

F. THE COMPLEXITY OF INDEPENDENT OPERATIONS $\ldots \ldots \ldots \ldots \ldots$

Senior Counsel, International, Nexen Inc. The author wishes to thank Jim MacLean (Land Manager, Chevron Canada Resources), Tim Martin (Vice-President and Special Counsel, Nexen Inc.), Craig Spurn (Partner, Blake Cassels \& Graydon) and Dr. M.I. (Joe) Josephson (father of the author) for their advice and assistance in connection with this article. 


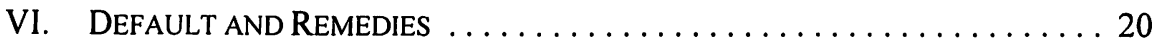

VII. OWNERSHIP AND DISPOSITION OF PRODUCTION $\ldots \ldots \ldots \ldots \ldots \ldots \ldots 22$

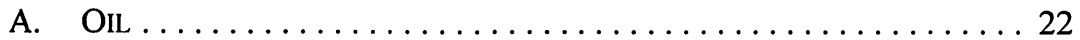

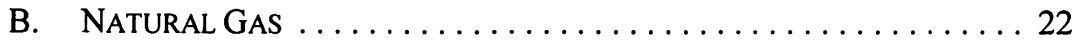

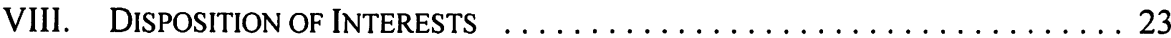

IX. Governing LaW and Dispute RESOlUtion $\ldots \ldots \ldots \ldots \ldots \ldots \ldots . \ldots 24$

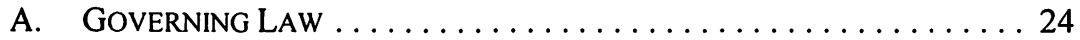

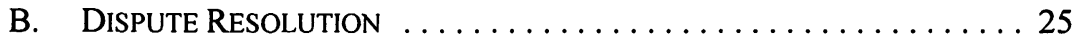

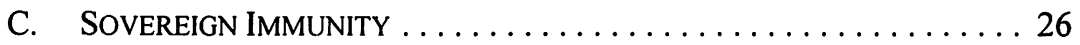

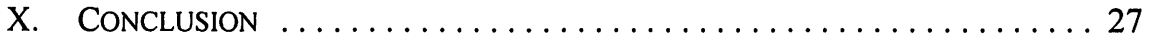

\section{INTRODUCTION}

\section{A. OVERVIEW}

Canadian exploration and production companies have been involved in international petroleum operations for several years. The commercial successes of Nexen in Yemen, Talisman in Sudan, and Talisman and Encana in the North Sea are well known. While international exploration was once the almost exclusive domain of the majors, even smaller Canadian explorers have in recent years begun setting their sails away from North American shores in search of new petroleum lands. As a result of increasing interest shown by Canadian companies in international exploration and production ventures, there is increasing demand for information and advice on common practices, standards and precedent agreements in effect and in use in the international petroleum industry.

One such common practice in the international petroleum industry is joint operations. The high finding costs associated with international explorations, which often take place in remote areas and on difficult terrain, and the inherent political risks associated with many international jurisdictions make joint operations on international projects especially attractive.

To govern their relationship in connection with international joint operations, participants negotiate joint operating agreements. Over time, model forms of operating agreements have been developed in order to reduce negotiating and drafting efforts on those aspects of the agreements which are of a standard or boiler-plate nature. Because such aspects usually form the largest part of any joint operating agreement, the use of a model form permits the participants to concentrate their efforts on the key commercial and contractual terms at issue in the specific transaction. Other benefits of utilizing widely accepted model form agreements as a starting point for negotiations include familiarity of concepts, consistency of drafting style and terms, broad-based industry analysis and input, and a developing body of academic and judicial interpretation.

Canadian explorers and producers are familiar with the concept of joint operating agreements. They are particularly familiar with the Canadian Association of Petroleum Landmen (CAPL) model form Operating Procedure, ${ }^{1}$ which is the widely accepted standard 
form joint operating agreement for conventional joint oil and gas operations in the Western Canadian Sedimentary Basin. The various versions of the model form CAPL Operating Procedure will be referred to in this article collectively as the "CAPLs."

There are various other model forms of operating agreements in use in other parts of the North American continent and the world. For onshore operations in the United States, the AAPL Form 610 model form Operating Agreement (AAPL 610) is a widely accepted form that was first developed by the American Association of Petroleum Landmen in the 1950s and has been revised and updated on several occasions since then, most recently in 1989. Other model forms have been developed for use in the U.S. Rocky Mountains, the U.S. deepwater Gulf of Mexico, Canadian frontier areas, the U.K. North Sea, Australia and elsewhere. For international jurisdictions outside of the aforementioned areas, a widely accepted form has been developed by the Association of International Petroleum Negotiators (AIPN). The various versions of the model form International Operating Agreement will be referred to in this article collectively as the "AIPNs."

Petroleum negotiators, lawyers and other representatives of Canadian companies asked to advise or assist in negotiations with respect to operating agreements for international petroleum ventures normally have backgrounds that are primarily in the context of Canadian operations. As such, they will usually have questions and concerns about concepts and drafting, and even drafting styles, in the proposed forms of operating agreements because they are different from those with which they are familiar within the CAPLs. Due to their relative familiarity with the CAPLs, these representatives may even be tempted to propose the CAPLs as the basis for the operating agreement, particularly in circumstances where all of the participants in the international venture are of Canadian origin.

It is a credit to the drafting committees of the CAPLs that the Canadian model form stands out among all model forms of operating agreements for the clarity of its wording, organization, and approach to concepts. The CAPLs have influenced the evolution of other model forms and are often referred to in American and international commentaries on joint operating agreements. However, the CAPLs, like other model forms, have evolved to reflect the particular industry standards, customs, laws, and regulations in effect in the jurisdictions in which they are most commonly used. Conventional operations in Western Canada tend to involve a relatively homogeneous group of players. In contrast, international operations often involve a variety of participants from disparate political, legal, and economic systems. The various participants may include state-owned oil companies whose agendas and expectations may be very different from the profit-driven goals of North American exploration and production companies. International projects tend to be larger in scale than most domestic operations, and are often located in places with very little infrastructure and where the cultural, political, legal, and economic environments are very different from those with which we are familiar in Canada. Moreover, the petroleum rights held by the participants will usually be derived from legal sources which are quite unlike conventional Canadian petroleum and natural gas leases. A workable international joint operating agreement must address these many distinctions. 
The drafting committees of the CAPLs and the AIPNs share many common objectives. These objectives include the need to balance the rights and obligations of operators and nonoperators, to balance the needs of the individual participants with those of the participants collectively, to make the negotiation process more effective by providing a widely accepted model form as a starting point for discussions among the participants, and to ensure that the model forms continue to reflect the contemporary needs of industry through a periodic updating process.

The objectives of this article are to identify key aspects of joint operations in respect of which the CAPLs and the AIPNs have taken different approaches and to consider the rationale behind the differences. I have focused primarily on the current versions of the CAPLs (1990) and the AIPNs (1995) as well as specific revisions which I anticipate will soon be made to both model forms. In this regard, both the CAPLs and the AIPNs are in the process of revision at the time of writing. I have served on the AIPN revisions committee chaired by Philip Weems of the Houston office of the American law firm King \& Spalding. The 2002 AIPN International Operating Agreement is expected to be approved by the AIPN board of directors and published in the first half of 2002. The 2003 CAPL Operating Procedure, as revised under the chairmanship of Jim MacLean of Chevron Canada Resources, is expected to be completed and published in the first half of 2003.

\section{B. LEgal NATURE OF THE Rights GRANTED}

In Western Canada, rights to hydrocarbons are conferred upon petroleum companies usually by way of petroleum and natural gas leases granted by freeholders or by the provincial or federal Crowns. It is well established in Canadian law that a petroleum and natural gas lease is a profit à prendre $e^{3}$ (a license to take something from the soil of another) and that the rights conferred thereby are not mere personal rights but rather, for many significant purposes, are interests in land. The characterization of petroleum and natural gas leases, and other interests derived therefrom as being interests in land (as opposed to mere personal rights) is significant to the determination of the rights and obligations incident thereto under statute and common law. In particular, the characterization of an interest as running with the land or as a mere personal or contractual right is of significance with respect to issues relating to conveyancing, land titles legislation, Statute of Frauds, rights of first refusal, options to purchase, overriding royalties and net profits interests, among others.

In jurisdictions outside Canada and the United States, hydrocarbons are almost always owned exclusively by the state. The petroleum laws of many states provide that petroleum and natural gas lying within their jurisdictions are the exclusive property of the state. Rights to explore for and produce hydrocarbons have been granted by states to foreign petroleum companies by way of a variety of arrangements, including concessions, production sharing agreements, service agreements, risk-service agreements and various hybrids of these. These arrangements are often referred to in the international petroleum industry as host government contracts or international petroleum contracts. 
Of the various types of host government contracts, the production sharing agreement (PSA), and hybrid forms thereof, are currently the most common types of arrangement governing international petroleum operations. PSAs are also referred to as production sharing contracts (PSCs).

Unlike some forms of concession agreements, which may contain hallmarks of ownership by the foreign petroleum company of minerals in situ, a PSA will often expressly state that the host government, at all times and for all purposes, owns and holds title to the hydrocarbon reserves in the contract area. This approach is consistent with the petroleum law of most states. The PSA will usually refer to the foreign petroleum company as a "contractor" and the relationship of the foreign petroleum company to the host government is impliedly, if not always expressly, characterized as that of a contractor for hire to the host government to provide exploration, development and production services. It is uncertain whether the rights granted to foreign petroleum companies under PSAs and other host government contracts would be viewed as being interests in land (as that concept is understood under Canadian common law) by a court or arbitral tribunal adjudicating a dispute among parties to an operating agreement. The answer may be of particular importance with respect to the availability of remedies in the case of a breach of the operating agreement (for example, the availability of the equitable remedy of specific performance against a party to the agreement or against a third-party transferee of an interest which is burdened by an unsatisfied right of first refusal).

As will be discussed later in this article, the nature and extent of a party's remedies under a joint operating agreement for breaches of the agreement by another party will depend on the state of the law in the host country (the laws of which usually govern the host government contract) and on the laws of the jurisdiction which is selected by the participants to govern their arrangement under the joint operating agreement. The laws of the host country will often be unsophisticated, or non-existent, with respect to remedies for breach of contract. Moreover, the laws of the jurisdiction selected by the parties to govern the joint operating agreement may also be unsophisticated and, in any event, may differ markedly from the remedial laws with which we are familiar in Canada. Consequently, the negotiators of an international joint operating agreement need to be more attentive to the issue of remedies and their enforcement than the negotiators of a domestic Canadian joint operating agreement would ordinarily be. For example, in contrast to domestic operating agreements, international operating agreements may contain detailed provisions designed to effect transfers of defaulting parties' participating interests to the non-defaulting parties, provisions expressly entitling aggrieved parties to specific performance, and provisions for liquidated damages.

Another significant distinction between Canadian petroleum and natural gas leases and international petroleum contracts is that the latter, unlike the former, do not generally entitle the participant petroleum companies to maintain their rights for so long as petroleum substances are produced or are capable of being produced from the lands. Rather, host government contracts generally continue after the commencement of the development phase only for a specified term of years. Consequently, petroleum companies engaged in international operations must plan for the eventual transfer of the operations to the host government prior to the end of the producing lives of the subject fields. 


\section{Production Sharing Agreements}

Although it is not the focus of this paper to describe or analyze host government contracts in detail, it will be helpful to describe, at least briefly, the structure of a PSA in order to illustrate the differences between this common source of petroleum and natural gas rights in international jurisdictions and Canadian forms of petroleum and natural gas leases. It must be kept in mind that there are many variations among PSAs, and the following is merely a simplified illustration of a typical arrangement.

Under a PSA, one or more petroleum companies will be granted an exclusive right to explore for and produce hydrocarbons for a fixed period of time in a specified area. As previously mentioned, the petroleum companies are referred to in the PSA collectively as the contractor. In consideration of the granted rights, the contractor agrees to undertake specified exploration activities ("minimum work obligations") or to spend a specified sum of money on exploration activities ("minimum expenditure obligations") or both. The minimum work obligations may include seismic surveys, the drilling of a well or the conduct of a multiple well exploration program. If no commercial discovery is made during the exploration term of the PSA, then the PSA will terminate without any compensation to the contractor. If a commercial discovery is made during the exploration term, then the contractor may elect to develop the discovery and the PSA will continue in respect of the producible area around the discovery.

Under a PSA, production is usually allocated first to cost oil to which the contractor is entitled as reimbursement for its exploration, development and production expenditures. The balance of production after the allocation of cost oil is profit oil, which is split between the government and the contractor on a sliding-scale basis. Theoretically, through the allocation of cost oil, the contractor is compensated for all of its capital and operating expenses over the life of the PSA (other than specific categories of expenditures as may be designated as non-recoverable under the terms of the PSA). Generally, only a portion of production (for example, 40 to 50 percent) is designated as cost oil in each year. To the extent that a contractor's recoverable costs exceed the amount of cost oil available in any year, the balance of costs is rolled over for recovery in subsequent years. The recovery of costs may also be limited by specified cost allowances or rates of recovery applicable to certain categories of expenditures. In this regard, a contractor's capital costs incurred in a given period may be recoverable at a rate of, for example, 25 percent. The purpose of these limits on cost recovery is to permit the contractor to recover its costs on a gradual basis while not preventing the host government from receiving a share of production even while substantial costs of the contractor are outstanding. 


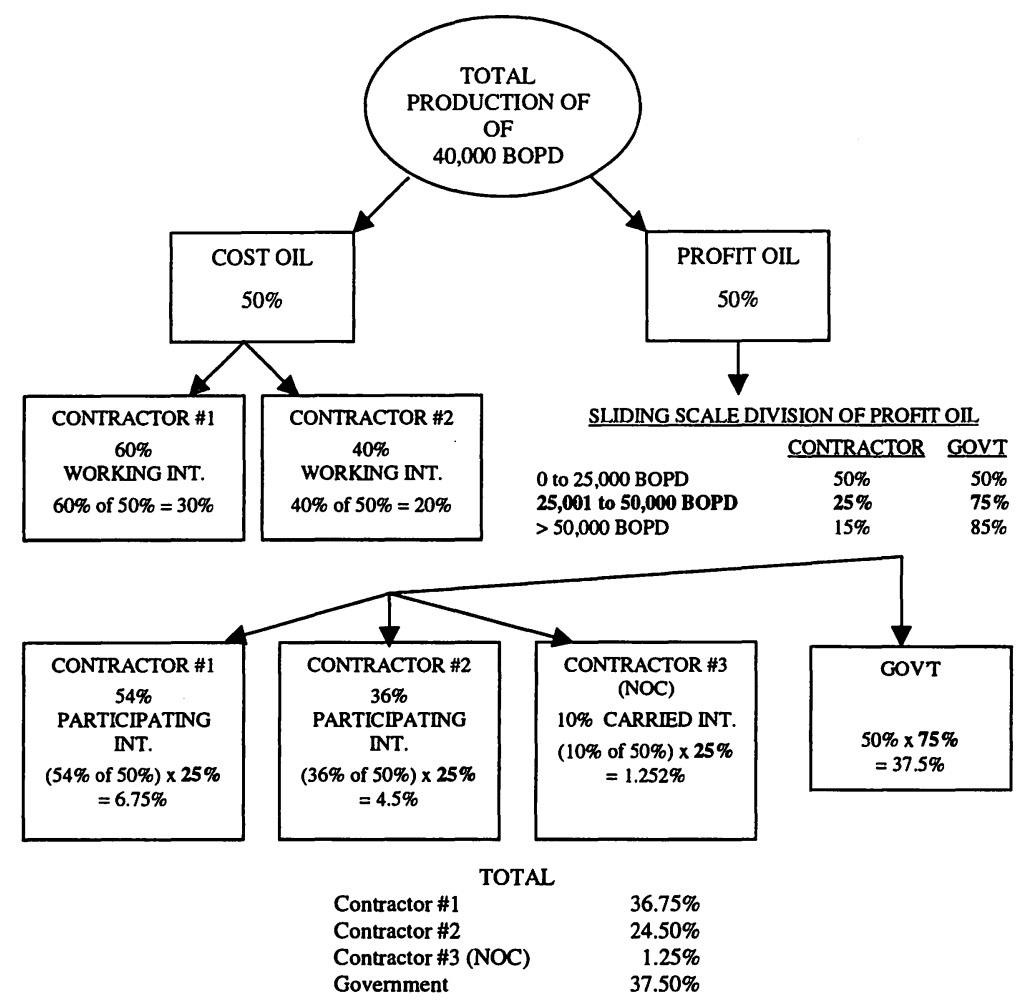

Profit oil is generally divided between the contractor and the government on a sliding scale determined by rates of production - that is, the greater the amount of daily production, the larger the percentage of profit oil which will be allocated to the government. Some PSAs will link the sliding scale to contractor profitability rather than rates of production, or to a combination of contractor profitability and rates of production.

In addition to its share of profit oil, a host government may also be entitled to various bonuses under the terms of a PSA, such as a signing bonus payable upon the signing of the PSA and production bonuses payable when designated production plateaus are attained. In addition, it is becoming increasingly common for host governments also to require that the national oil company or other government-affiliated entity be a party to the PSA and a participant in petroleum operations (sometimes on a carried basis, sometimes on a noncarried basis) together with the contractor.

The basic and general terms of a PSA described herein serve to illustrate the distinct differences between international petroleum arrangements and those with which we are familiar in western Canada. It is important to recognize and account for these differences when negotiating and drafting an international joint operating agreement. 


\section{STYLE OF THE FORMS}

Those readers who have reviewed the AIPN model form will have noticed that it includes an extensive number of alternative provisions and optional clauses which can be selected or rejected by the parties depending on their points of view. It has been suggested by some commentators that the sheer number of alternatives and options in the AIPN model form makes it awkward to use and that it impedes negotiations because every election must be the subject of discussion and debate among the parties. However, the international industry is comprised of a wide variety of participants - from publicly-traded super-majors to small private promoters to state-owned oil companies - each with broadly different expectations and agendas. In an effort to achieve the widest possible use of the model form, the AIPN has adopted and is intent on maintaining the concept of including options and alternatives where necessary to reflect legitimate differences of opinion and practice in the international industry. A further criticism by some commentators is that, by incorporating so many elections, the AIPN misses the opportunity to set international industry standards. However, such a criticism is easily made if one assumes that one's favoured position on an issue will be adopted in the model form. This assumption is not a safe one given the significant differences in practice and opinion which exist on a variety of issues in the international petroleum industry. In any event, the AIPN model forms have served to set standards in several areas.

In contrast to the AIPNs, the CAPLs contain a relatively modest number of elections. The approach of the CAPLs can be explained, in part, by the generally greater degree of uniformity in expectations and agendas among participants in the domestic industry than among participants in international operations. However, the approach also reflects a philosophy of the CAPL drafting committees in favour of standardization. Nevertheless, there appears to be a movement in the Canadian industry towards what Jim MacLean, the chairman of the 2003 CAPL Operating Procedure revisions committee, calls "norm-based standards." Norm-based standard documents have been described as model forms which reflect the most common standards and approaches but which are intended to be modified in appropriate circumstances to address the special requirements of specific transactions. ${ }^{4}$ Some recent model forms, such as the 1997 CAPL Farmout \& Royalty Procedure, the 1997 CAPL Overriding Royalty Procedure and the 2000 CAPL Property Transfer Procedure, reflect the trend towards norm-based standards. The 1990 and prior versions of the CAPLs have been more in keeping with a pure standardization approach in which few changes to the model form are expected to be negotiated by the parties. It is likely that the 2003 version of the CAPL model form will be more closely aligned with a norm-based standards approach by the inclusion of an increased number of annotations describing circumstances in which the parties may wish to consider modifications to the model form. 


\section{OPERATORSHIP}

\section{A. APPOINTMENT AND REPLACEMENT OF OPERATOR}

Both the CAPLs and the AIPNs provide for the designation of one of the participants as operator and also for the circumstances in which operatorship is subject to change. While there are some differences in approach and procedure between the two model forms in this area, most of the differences result more from the separate evolution of the two forms than from any distinction between the domestic Canadian and international petroleum industries with respect to changes in operatorship. In fact, with respect to some provisions, the CAPLs and the AIPNs are more closely aligned with each other than with other prominent model forms, such as the AAPL 610. For example, both the CAPLs ${ }^{5}$ and the AIPNs ${ }^{6}$ provide for the removal of an operator without cause upon the affirmative votes of a certain number of participants collectively holding at least a certain percentage participating interest. In contrast, the AAPL 610 - which is an industry standard for onshore operations in the United States - permits the removal of an operator only for good cause. While the AIPN's removal without cause provision is merely an optional election, the inclusion in the international model form of this powerful and controversial tool in favour of non-operators illustrates that the Canadian industry is in some respects more reflective of international standards than is the American industry.

The most significant distinction between the international and Canadian industries with respect to changes in operatorship is that, in an international operation, a designation of operatorship will be made not only in the joint operating agreement but often also in the underlying host government contract. Consequently, any change in operatorship under the terms of an international operating agreement cannot practically become effective until the host government has given its approval. This is recognized in the AIPN model form by the inclusion of a requirement for host government approval as a condition precedent to any change in operatorship. ${ }^{7}$

\section{B. CONDUCT AND STANDARDS OF OPERATOR}

Like the CAPLs, the AIPNs include general statements concerning the operator's conduct of operations and proper practices as well as an enumeration of specific responsibilities. While there are various distinctions between specific rights and obligations of operators under the CAPLs and AIPNs (the more significant of which will be considered elsewhere in this article), both model forms generally purport to hold the operator to similar levels of conduct and standards. For example, under the CAPLs, the operator is required to conduct joint operations diligently, in a good and workmanlike manner, and in accordance with good oilfield practice and applicable laws. ${ }^{8}$ Under the AIPNs, the operator is required to conduct joint operations in a diligent, safe and efficient manner in accordance with good and prudent oilfield practices and conservation principles generally followed by the international

CAPL Operating Procedure (1990) at \$202(b)(i) [1990 CAPL].

AIPN Model Form International Operating Agreement (1995) at \$4.10, Optional Provision (E) [1995 AIPN].

Ibid. at $\$ 4.11(\mathrm{~F})$.

Supra note 5 at $\$ 304$. 
petroleum industry under similar circumstances. ${ }^{9}$ The 2002 version of the AIPN model form is likely to add an express requirement that the operator perform operations in compliance with the applicable laws of the host country, which will make the new version even more consistent with the CAPLs in terms of its general standard of operator conduct.

With respect to fiduciary obligations of operators to non-operators, the extent to which such obligations may be imposed upon some aspects of the relationship between operators and non-operators is an uncertain and troublesome area of law in many jurisdictions. In an attempt to resolve the uncertainty among parties to the operating agreement, the AIPNs expressly disclaim fiduciary duties. ${ }^{10}$ Issues of fiduciary obligations of operators to nonoperators " and implied duties of good faith in operators' performance of operating agreements ${ }^{12}$ are developing areas of Canadian law. Many of the leading cases in this area, and particularly those of direct relevance to the oil and gas industry, have been decided since the publication of the CAPL 1990 model form. Although the present trend in Canadian law appears to be away from the expansion of fiduciary obligations of operators to non-operators, the uncertainty in this area is of as much concern to Canadian operators as it is to international operators. Consequently, future versions of the CAPLs may address the issue in similar fashion to the AIPNs.

\section{LimitaTIONS ON LiABILITY OF OPERATOR}

Both the CAPLs and the AIPNs limit operators' personal liability for acts and omissions in the course of their conduct of operations to a standard of gross negligence and wilful misconduct. ${ }^{13}$ The effect of this limitation is that liability flowing from an operator's conduct, even negligent conduct (other than conduct which is intended to cause harmful consequences or is grossly negligent in the sense that it is in reckless disregard of or wanton indifference to harmful consequences) will be shared by all of the participants in accordance with their respective participating interests in the joint operating agreement. The rationale for this limitation of liability is that the operator is performing a gratuitous function for the benefit of itself and the other participants for which, as the AIPNs expressly state, the operator is to "neither gain a profit nor suffer a loss." ${ }^{14}$ Certainly the operator, being the party responsible for the conduct of operations, is more vulnerable than non-operators to the claims of third parties, including subcontractors, host governments and their agencies, and landowners, individuals, and entities impacted by operations.

Although the operator's standard of care is similar under the CAPLs and the AIPNs, there are significant distinctions between the two model forms with respect to the consequences to the operator for a breach of the required standard. Under the CAPLs, the operator is solely

Supra note 6 at $\$ 4.2(\mathrm{~B})(2)$.

Ibid. at $\$ 14.1$.

See e.g. Luscar Ltd. v. Pembina Resources (1994), 162 A.R. 35 (C.A.), leave to appeal to S.C.C. refused [1995] S.C.C.A. No. 6; and Moco Resources v. Unocal Canada Resources (1997), 204 A.R. 246 (Q.B.).

12 See e.g. Mesa Operating Limited Partnership v. Amoco Canada Resources (1994), 149 A.R. 187 (C.A.), leave to appeal to S.C.C. refused [1994] S.C.C.A. No. 202.

1.3 Supra note 5 at $\$ 401$; and supra note 6 at $\$ 4.6$, Optional Provision (D).

$14 \quad$ Supra note 6 at $\$ 4.2(\mathrm{~b})(3)$ 
responsible for liabilities resulting from its actions or omissions which amount to gross negligence or wilful misconduct. Under the AIPNs, the extent of the operator's liability will depend on which one of three alternatives were selected by the parties in the operating agreement. In this regard, the operator may be required to bear: (1) responsibility for all costs and liabilities; (2) responsibility only for the actual cost and liability to repair, replace, and/or remove damaged or lost joint property; or (3) responsibility for all costs and liabilities up to an agreed limit. ${ }^{15}$ If either of the latter two alternatives is selected, then any additional liability incurred by the operator in excess of the prescribed limitations will be borne by all participants (including the operator) in accordance with their respective participating interests under the operating agreement. The magnitude of potential losses is generally greater in international operations than in domestic ones and, consequently, qualified companies may refuse to take on the responsibility of operatorship of an international project if their exposure to claims is not limited even in situations where their conduct is found to be grossly negligent.

Another significant distinction between the CAPLs and the AIPNs is their treatment of environmental, punitive, consequential, and other similar indirect losses and damages. The AIPNs protect the operator from such losses and damages on the basis that the enormous potential exposure which may result therefrom in international petroleum projects would serve as a significant disincentive to qualified, solvent companies to act as operators. Where any such losses or damages are suffered or incurred by the operator, all participants (including the operator) are required to share them in accordance with their respective participating interests under the operating agreement. ${ }^{16}$ In contrast, the CAPLs protect the operator only for losses suffered by the non-operating participants respecting the loss or delay of production from the joint lands. ${ }^{17}$ Even though the CAPLs address one of the most likely types of consequential damages in a petroleum operation (damages resulting from the loss or delay of production), the scope of the CAPL exclusion of consequential damages is exclusive, whereas the scope of the AIPNs is without limitation. ${ }^{18}$

The CAPLs' limitations in respect of consequential damages were introduced in the 1990 version of the model form, following the trend in the international and American industries toward the limitation of operators' liability. The issues of operators' standards of care and liability are currently being examined by the revisions committees of the CAPL and Canadian frontier model forms. In deciding whether greater limitations to operators' liability are warranted in western Canada operations, the CAPL revisions committee must consider the potential magnitude of losses in typical western Canada operations in comparison to international and Canadian frontier projects. The committee must also consider the objective of achieving an appropriate balance between the rights of operators and non-operators.

$15 \quad$ Ibid. at $\$ 4.6$, Optional Provision (D).

16. Ibid.

$17 \quad$ Supra note 5 at $\$ 401$.

18 The provisions of $\$ 4.6$ of the 1995 AIPN, supra note 6 , are intended to limit an operator's tortious liability to third parties and non-operating participants in connection with its performance or lack of performance of its duties and functions as operator. Whether intentional or not, $\$ 4.6$ may also have the effect of limiting an operator's liability to non-operating parties for breach of contract. Even if there is doubt in this regard, the operator can rely on other exclusion clauses, such as $\$ 18.2(C)(8)$, which excludes consequential, punitive or other similar damages from being allowed in any arbitration award made against any participant in favour of any other participant. 


\section{JOINT OPERATIONS}

\section{A. OPERATING COMMITTEES AND THE ROLE OF NON-OPERATORS}

What would appear, at least on the face of it, to be a significant distinction between the AIPNs and the CAPLs is the extent to which non-operators participate in the authorization and supervision of joint operations. In this regard, the AIPNs establish an operating committee to "provide for the overall supervision and direction of Joint Operations composed of representatives of each Party holding a Participating Interest." ${ }^{19}$ Each party is entitled to appoint one representative and one alternate representative to the committee. These representatives are entitled to attend committee meetings, as are such technical and other advisors as a party considers appropriate. The operating committee has the "power and duty to authorize and supervise Joint Operations that are necessary or desirable to fulfill the Contract and properly explore and exploit the Contract Area in accordance with this Agreement and in a manner appropriate in the circumstances." ${ }^{20}$ This language confers broad authority on the operating committee and one can argue that it provides non-operators with considerable power.

In contrast to the AIPNs, the CAPLs include only a duty on the part of the operator to consult with non-operators from time to time, ${ }^{21}$ and a right in favour of the non-operators to request from the operator a written forecast of proposed operations and an estimate of applicable costs. ${ }^{22}$

The concept of operating committees in international operations has developed due to the scale of most international projects in comparison to many domestic ones, their costs and risks, and the remote locations in which they take place. Considerable advance planning and budgeting are required in order to obtain the necessary services and equipment from contractors and to move the necessary materials and personnel into place in the area of operations. It is understandable that non-operators would insist on being formally consulted with respect to major aspects of large and risk-prone international ventures and on playing an active role in the decision-making process. The reason that the concept has not been adopted in the Canadian onshore industry is explained in the explanatory notes of the annotated version of the 1990 CAPL model form:

[I]t is not feasible to include a management committee provision in the document. A typical operator will be operating a multitude of blocks with varying partners, interests, tenures, prospectivity, maturity and activity. It would not be reasonable to impose a management committee procedure on an operator with respect to each block it operates because of the resultant administrative burden. ${ }^{23}$ 
Operating committees have been likened to corporate boards of directors. ${ }^{24}$ However, despite the seemingly broad powers and duties conferred upon the operating committee, the operator is expressly given the exclusive charge of joint operations. ${ }^{25}$ It has been observed that whether the operating committee actually acts as an active and influential body in the style of a corporate board of directors or whether it merely serves as a "rubber stamp" for the operator will depend upon the dynamics of the group. ${ }^{26}$

\section{B. WORK Programs AND BUdgets}

Considerable advance planning and budgeting are required in international operations due to their costs and risks, and due to the remote locations in which they take place. To facilitate the necessary planning and budgeting, the AIPNs require an annual work program and budget to be submitted by the operator for the approval of the operating committee. ${ }^{27}$ Also, most PSAs will require the operator to submit an annual work program and budget for the approval of the host government. It is important that the work program and budget approved under the operating agreement be consistent with the work program and budget submitted for approval under the PSA. There are no similar requirements in the CAPLs apart from the operator's obligation to provide, for informational purposes only, a written forecast of proposed operations and an estimate of applicable costs at the request of a non-operator. ${ }^{28}$

\section{AUTHORITY FOR EXPENDITURE}

There are notable differences between the CAPLs and the AIPNs with respect to the use and purpose of authorizations for expenditure (AFEs). The CAPLs require the operator to obtain an approved AFE from the non-operators prior to making or committing to an expenditure for the joint account which is in excess of 25,000 dollars (CDN). ${ }^{29}$ The 1995 version of the AIPN model form also requires the operator to send AFEs to non-operators, but the financial limits are left unspecified so that the parties can insert their own monetary thresholds at the time the operating agreement is negotiated. ${ }^{30}$ Also, the AIPN model form allows the parties to set different financial limits for the exploration and appraisal phase, the development phase and the production phase of operations. ${ }^{31}$

In the CAPLs, AFEs are mandatory for expenditures in excess of 25,000 dollars (CDN) unless the expenditure is in respect of an event endangering life or property or is required by applicable law where the failure to make the expenditure could result in prosecution of the

A.B. Derman, Model Form International Operating Agreement: An Analysis and Interpretation of the 1995 Form (American Bar Association, Section of Natural Resources, Energy, and Environmental Law, Monograph 23, 1997) at 35.

Supra note 6 at $\$ 4.2(\mathrm{~A})$.

Supra note 24.

Supra note 6 at Article VI.

Supra note $5 \$ 504$. In practice, non-operators rarely make use of the forecast mechanism in conventional operations. The annotations to the 2003 version of the CAPL model form will likely include a suggestion that this provision be modified by the parties in appropriate circumstances, such as a large capital project.

Ibid. at $\$ 301(b)$.

Supra note 6 at $\$ 6.6(\mathrm{~A})$.

Ibid. 
operator. ${ }^{32}$ In the AIPNs, the parties must elect whether AFEs: (1) are for informational purposes only; (2) are mandatory; or (3) may only be disapproved by a party on the grounds of certain specified criteria. ${ }^{33}$ Where operations are rejected by the parties on the basis of (2) and (3), the work program and budget are deemed to be revised accordingly. ${ }^{34}$

Given the procedures in the AIPNs for the approval of annual work programs and budgets, several questions are raised with respect to AFEs in an international context. For example, why would AFEs be required at all? Also, what is the purpose of the AFE (that is, are they to be merely for information, or are they to be submitted for approval or rejection)? These questions can be the subject of protracted negotiations, not to mention confusion on the part of personnel in an international operation who may be more familiar with the traditional, mandatory concept of AFEs in the CAPLs. The arguments in favour of including an AFE approval process in an international operating agreement in addition to the process for approval of annual work programs and budgets include the need for participants to coordinate and plan for expenditures and to provide for a degree of control over the operator. ${ }^{35}$ However, given that the concept of an annual work program and budget is designed to facilitate planning and budgeting for costly and logistically challenging operations in remote locations, a two-step approval process seems to lack efficiency and may be susceptible to abuse by parties who make commitments at the annual budgeting stage knowing that they will have an opportunity to withdraw their commitments at the AFE stage. The 2002 version of the AIPN model form is likely to include an option to dispense with the AFE process in its entirety.

\section{SUPPLEMENTAL AUTHORIZATIONS FOR EXPENDITURE}

Under the 1974 and 1990 versions of the CAPL model form, the general rule is that the approval of an AFE constitutes the authority of a party for the operator to conduct the operation described in the AFE, notwithstanding that the actual cost may differ from the operator's estimate. ${ }^{36}$ The 1990 version expressly requires the operator to notify the nonoperators, for informational purposes only, and provide them with a revised estimate of costs if the operator incurs or expects to incur expenditures exceeding by more than 10 percent the amount approved in an AFE. ${ }^{37}$

Under the AIPNs, where an overexpenditure in respect of any line item of an approved work program and budget will exceed by more than 10 percent the authorized amount for that

Supra note 5.

Supra note 6 at $\$ 6.6(\mathrm{~B})$.

Ibid. at Alternative Provisions 2 and 3.

Supra note 24 at 55 and 57.

In respect of the 1974 version of the CAPL model form, the issue was dealt with in Metalore Resources v. Renaissance Resources, [1984] 4 W.W.R. 430 (Alta. Q.B.), aff'd [1985] 4 W.W.R. 673 (Alta. C.A.), leave to appeal to S.C.C. refused, [1985] 1 S.C.R. X. The issue was decided differently in Morrison Petroleums v. Phoenix Canada Oil (1997), 198 A.R. 81 (Q.B.) [Morrison], a case involving the 1981 version of the CAPL model form. A significant factor in Morrison was the wording of $\$ 301$ of the 1981 version. It is unlikely that the same result would occur under the 1990 version because the wording of $\$ 301$ has been changed from that employed in the 1981 version.

Supra note 5 at $\$ 301(\mathrm{c})$. 
line item, a supplemental AFE must be furnished to the operating committee for approval. ${ }^{38}$ Overexpenditures are also limited to a cumulative total of 5 percent of an annual work program and budget in any year. ${ }^{39}$ It is interesting to consider what consequences would result from an overexpenditure by the operator which exceeds the prescribed limits but does not receive the requisite approval of the operating committee. Is the supplemental AFE for informational purposes only or is the approval of the operating committee a mandatory requirement? If the issue were brought before the Alberta courts, it might well be determined on a basis similar to that in Morrison, ${ }^{40}$ in which the Court held, in the context of the 1981 version of the CAPL model form, that in the absence of an approved supplemental AFE, the non-operators were not liable to the operator for cost overruns in excess of the prescribed threshold of 10 percent of the original AFE. A significant factor in the Morrison decision was the mandatory language of clause 301 of the 1981 version and the fact that, unlike the 1990 version, the 1981 version contained no express statement that supplementary AFEs are for informational purposes only. The AIPNs contain mandatory-sounding language similar to that employed in the 1981 version of the CAPL model form and, like the 1981 version, do not contain an express statement that supplementary AFEs are intended for informational purposes only. However, it is unlikely that the issue will ever be brought before an Alberta court. Alberta law is rarely chosen as the governing law of international operating agreements. Moreover, questions of interpretation of international petroleum agreements, such as the AIPNs, are rarely resolved in the courts of any jurisdiction, but rather are settled privately or are resolved through arbitration processes. Although the AIPNs are unclear on this point, a plausible argument can be made in some circumstances that overexpenditures which exceed the prescribed limits are not the responsibility of the operator to assume but rather are properly chargeable to the joint account of the participants. ${ }^{41}$

\section{E. Approval Process}

Under the CAPLs AFEs must be unanimously approved by all of the joint operators. ${ }^{42}$ If an AFE is not approved by all of the joint operators, the operation proposed in the AFE can still go forward as an independent operation under article X. Under the AIPNs, several alternatives are included so that the participants may select a general passmark for approval of proposals for operations coming before the operating committee or specific passmarks for

Supra note 6 at $\$ 6.7(\mathrm{~A})$.

Ibid.

Supra note 36.

In this regard, consider article 4.2(B)(2) of the 1995 version of the AIPN model form, which provides that the operator is to conduct "all Joint Operations in a diligent, safe and efficient manner in accordance with good and prudent oilfield practices and conservation principles generally followed by the international petroleum industry under similar circumstances." Given the nature of the international oil and gas industry, an operator may not reasonably be in a position to know that the overexpenditure limits have been exceeded until the operation is completed and the overexpenditure has been incurred. Depending on the nature and cost of a particular operation, the overexpenditure limits could be exceeded within a matter of hours or days. Even if the operator is aware that overexpenditures will or are likely to exceed the limits, would it be considered good and prudent oilfield practice, for example, to stop an operation pending the furnishing and approval of a supplemental AFE while a rig is standing by at significant expense? Consider also article 4.2(B)(3) of the same model form, which provides that the operator is to "neither gain a profit nor suffer a loss as a result of being the Operator in its conduct of Joint Operations." 
various major operations which are identified in an enumerated list contained in the model form. ${ }^{43}$ Proposals which do not receive the requisite approvals of the operating committee may, subject to various exceptions, go forward as independent operations.

\section{INDEPENDENT OPERATIONS}

\section{A. OVERVIEW}

What are referred to as independent operations under the CAPLs are called exclusive operations under the AIPNs. Independent or exclusive operations are also commonly known in the international petroleum industry as sole risk operations. For the purposes of this article, such operations will be referred to as independent operations. With respect to independent operations, the CAPLs and the AIPNs share the same general philosophy: to encourage joint operations, while neither forcing parties to participate in operations if they do not wish to do so, nor prohibiting parties from proceeding with operations in which some parties do not wish to participate.

\section{B. RESTRICTIONS ON INDEPENDENT OPERATIONS}

Unlike domestic programs, international projects require the participants to agree to undertake specific work and expenditure commitments during the exploration phase of, and under a development plan approved pursuant to, the underlying host government contract. As a result, the AIPNs are somewhat more restrictive than the CAPLs regarding the operations which can be proposed and conducted as independent operations. For example, operations which are required to fulfill the minimum work obligations under the host government contract may not be conducted as independent operations. ${ }^{44}$ No operation pursuant to an approved development plan may be conducted as an independent operation, ${ }^{45}$ and no independent operation may be conducted which conflicts with a joint operation. ${ }^{46}$ Parties must either participate in operations that cannot be the subject of an independent operation or withdraw from the operating agreement. ${ }^{47}$ However, a withdrawing party will remain liable for its share of minimum work obligations under the host government contract and for the cost of all operations in which it had agreed to participate that were approved as part of a work program and budget or AFE prior to its notification of withdrawal. ${ }^{48}$

Ibid. at $\$ 7.1(\mathrm{~B})$. Note that $\$ 7.1(\mathrm{~B})$ contains an optional provision which, if selected, would permit independent operations beyond the drilling of a well (deepening, testing, completing, sidetracking, plugging back, recompletions, and reworking) where the minimum work obligations under the host government contract in respect of that well have been fulfilled, but the total minimum work obligations under the host government contract have not yet been fulfilled in their entirety.

Ibid. at $\$ 7.1(\mathrm{D})$.

Ibid. at $\$ 7.1(\mathrm{~A})$.

In some situations, depending upon the terms of the host government contract and the willingness of the host government to consent, a non-participating party may partially withdraw from the operating agreement by withdrawing from that portion of the contract area which is the subject of a development plan but remaining as a participant in other portions of the contract area.

Supra note 6 at $\$ 13.4(\mathrm{~A})$. 
Under the AIPNs, an operation may not proceed as an independent operation until it has been properly proposed to the operating committee as a joint operation. ${ }^{49}$ In contrast, under the CAPLs any party may at any time propose the conduct of an operation on the joint lands, subject to some narrow restrictions for wells in close proximity to other wells being drilled under the operating agreement. ${ }^{50}$

Where there are conflicting proposals for operations, the CAPLs utilize a first-in-time approach to determine priority, whereas the AIPNs utilize a voting procedure to select the most desirable proposal. In the case of a tie, the operator has the deciding vote. ${ }^{51}$

\section{REINSTATEMENT AND RELINQUISHMENT OF RIGHTS}

There are significant differences between the CAPLs and the AIPNs with respect to reinstatement or back in rights of non-participating parties and the penalties which apply to such rights. Under the CAPLs these rights and penalties apply on a well-by-well basis, whereas under the AIPNs the rights and penalties apply on a field-wide basis. The differences in approach can be explained largely by the relative scale of domestic operations in comparison to international projects.

In general, under the CAPLs (except with respect to title preserving wells), if a well is completed for the production of petroleum substances from one or more zones, the participating parties are entitled to retain possession of the well and all production from such zones through the well until the participating parties have recovered their costs of the operation plus specified penalties. ${ }^{52}$ Upon full recovery of such costs and penalties (commonly referred to as "payout"), the non-participating parties have the automatic right to elect to accept or refuse participation in the well, the applicable zones and production therefrom. Non-participating parties who elect to accept participation then have their original entitlement reinstated. A failure to elect within the prescribed time is deemed to be an election to participate. Non-participating parties who refuse participation are deemed to have forfeited their rights of participation in the well and to the spacing unit of the well as it relates to the applicable zones and the production therefrom. ${ }^{53}$

Under the AIPNs a non-participating party is deemed from the outset of an independent operation to have relinquished to the participating parties its participating interest in the wellbore drilled pursuant to that operation (or that portion of the wellbore which is the subject of that operation), as well as any future appraisal and development wells in respect of any discovery made in the course of that operation. ${ }^{54} \mathrm{~A}$ non-participating party has the right to reinstate its relinquished rights only in certain specified circumstances. Such circumstances include a decision by the participating parties to appraise a discovery made in the course of the independent operation or to develop a discovery made or appraised in the course of the independent operation. In such circumstances, a non-participating party is given

\footnotetext{
4) Ibid. at $\$ 7.1(\mathrm{C})$.

50 Supra note 5 at $\$ 1002$.

51 Supra note 6 at $\$ 7.6(\mathrm{C})$

$52 \quad$ Supra note 5 at $\$ 1007$.

$3 . \quad$ Ibid.

54 Supra note 6 at $\$ 7.4(B)$.
} 
a certain number of days (or hours, if a drilling rig which is to be used in an appraisal program is standing by) to elect to accept participation. A failure to elect within the prescribed time is deemed to be an election to refuse participation. ${ }^{55}$

\section{Penalties (Premiums)}

Under the CAPLs the only mechanism provided for the recovery by the participating parties of their costs of an independent operation and applicable penalties is the right to take the non-participating parties' shares of production until payout, at which time the nonparticipating parties are entitled to make their elections to accept or refuse participation. Under the AIPNs the costs of an independent operation are treated separately from the applicable penalties (or premiums as they are called in the AIPNs). To compensate the participating parties for their past costs of the independent operation, a non-participating party which has elected to accept participation must make to the participating parties, within thirty days of its election, a lump-sum cash payment in an amount equal to such past costs. ${ }^{56}$ With respect to the applicable premiums, the AIPNs provide alternatives for selection by the parties at the time of the negotiation of the operating agreement. In this regard, the parties may select different percentage amounts for premiums that will apply to specific types of operations (that is, to exploration wells and to appraisal wells), ${ }^{57}$ and must select the manner in which the premiums will be satisfied. The parties may specify that premiums are to be satisfied by way of a lump- sum cash payment ("cash premium"), or by allowing the participating parties to take the non-participating parties' share of production temporarily ("in kind premium"). ${ }^{58}$ The in kind premium mechanism is similar to the penalty mechanism utilized in the CAPLs.

In practice, in kind premiums are rarely utilized in international operations. The parties to an international operating agreement will almost always select the cash premium alternative. One commentator has, with disparaging humour, referred to the concept of in kind premiums as the Petroleum Accounting Full Employment Act ${ }^{59}$ As a result of the infrequency with which in kind premiums are selected by parties to international operating agreements, the 2002 version of the AIPNs is likely to remove this alternative mechanism from the model form and replace it with a new alternative mechanism that would require nonparticipating parties to bear temporarily all of the participating parties' future cash calls until the premium has been satisfied (a concept referred to as "disproportionate spending").

\section{E. OPERATORSHIP OF INDEPENDENT OPERATIONS}

Under the CAPLs the party proposing the independent operation (even if that party is not the existing operator) is generally entitled to become the operator of the independent operation. The existing operator would then succeed the proposing party as operator with respect to such operation upon its completion. ${ }^{60}$ In contrast, the AIPNs obligate the existing 
operator to conduct the operation even if it has elected not to participate. ${ }^{61}$ While it may seem imprudent to leave operatorship in the hands of a non-participating party, it must be kept in mind that the operator designated under an international operating agreement is often also designated as operator in the underlying host government contract which requires host government approval to change. Consequently, having separate operators for joint operations and independent operations is impractical in many cases. It is interesting that the AIPNs do not provide a non-participating operator with any compensation for its work or with any special indemnities, limitations of liability or exemptions from liability in respect of its conduct of independent operations, other than the indemnities, limitations and exemptions which are generally applicable to a participating operator. It is not difficult to imagine an operator's lack of enthusiasm for being required to conduct independent operations from which it will not benefit and for which it will not be compensated, but in respect of which it may nevertheless be held liable in its capacity as operator.

\section{F. THE COMPLEXITY OF INDEPENDENT OPERATIONS}

Independent operations concepts are significantly more complicated in international projects than in domestic operations. The major reason for this is that the rights and obligations under host government contracts in general, and PSAs in particular, are not well suited to activities other than joint operations. As an example of the issues that need to be carefully addressed, consider the mechanisms under a PSA for the allocation of cost oil and profit oil. Under a PSA, cost oil and profit oil will usually be allocated on an aggregate basis to the entire contract area rather than separately by production area. However, it is possible for discoveries of hydrocarbons to be made and developed in one or more separate areas covered by the PSA. Some of these production areas may be held by all parties as joint operations and others may conceivably be held by fewer than all parties as independent operations. Consequently, an international operating agreement must contain a mechanism to distribute cost oil and profit oil among the parties in a fair manner. This will usually be accomplished by treating each production area as though the PSA applied separately to that area. However, this may result in an excess amount of cost oil in some instances where a particular production area has insufficient expenses to utilize all of the cost oil allocated to it. Under a typical PSA, excess cost oil is dealt with as though it were profit oil. As the host government is entitled to a share of profit oil, the oil companies will benefit if they use cost oil to its maximum extent and avoid having it characterized as profit oil. In order to do so, the operating agreement must contain a mechanism to reallocate excess cost oil from one production area to other production areas that can use it. However, the method of reallocating excess cost oil may generate considerable debate among the parties. For example, should the reallocation favour joint operations by being distributed first to production areas in which all parties are participating or should it be distributed to operations in the sequence developed, regardless of whether they are joint operations or independent operations?

.1 Supra note 6 at $\$ 7.2(E)$. An exception is contained at $\$ 7.11(F)$ in respect of independent operations to develop a discovery in which the operator has elected not to participate. In this circumstance, the operator may resign (subject to host government approval) and shall resign at the request of the participating parties as operator for the delineated exploitation area for such discovery, and the participating parties shall select another party to serve as operator. 
The foregoing example is but one of the many issues relating to independent operations which need to be addressed in an international operating agreement, but would not be necessary to address in a domestic agreement. Independent operations are not common in the international industry, probably largely due to the complexities associated with them. As a result, independent operations provisions in international operating agreements are often rather poorly thought out and drafted. Negotiating parties often do not have sufficient time to address the issues properly. The problem is compounded by parties who do not take independent operations provisions seriously because they anticipate that operations will either proceed jointly or not at all. The AIPN model forms go a long way toward rectifying the common deficiencies relating to independent operations found in many international operating agreements. However, even the Exclusive Operations provisions of the AIPNs contain some provisions which will seem confusing, particularly to persons without a strong background in international transactions. This is further testament to the difficulty of drafting in this area.

\section{Default AND Remedies}

To secure payment of a party's share of joint account expenses, the CAPLs create a lien and charge in favour of the operator with respect to the interest of each party in the joint lands. ${ }^{62}$ If a party defaults in the payment or advance of joint account expenses, the operator has a number of prescribed rights arising from the lien and charge in addition to any other rights it may have at law or equity. Such prescribed rights include the ability to withhold from the defaulting party any further information and privileges with respect to operations, ${ }^{63}$ the right to take the proceeds of sale of the defaulting party's share of production, ${ }^{64}$ and the right to enforce the lien by taking possession of and selling the defaulting party's interest in the joint lands. ${ }^{65}$ An operator's ability to enforce its rights against a defaulting party under the CAPLs is assisted by a well-developed body of common law, equitable principles and mechanisms provided by provincial and federal statutes.

Under the AIPNs a defaulting party must be given five business days notice to remedy its default, following which its rights under the operating agreement will be temporarily suspended. ${ }^{66}$ During the period of suspension, the defaulting party is prevented from attending at operating committee meetings and voting, from receiving data and other information relating to joint operations, and from receiving its share of production (which may be sold by the operator to recover the amounts owed by the defaulting party under the operating agreement and to fund a reserve for the defaulting party's share of eventual abandonment costs).$^{67}$ The AIPNs also provide that the defaulting party shall be deemed to have elected not to participate in any operations proposed during the period of suspension. ${ }^{68}$ In essence, the defaulting party is treated as though it were a non-participating party in an independent operation. As a result, the premiums payable by a non-participating party to

Supra note 5 at $\$ 505(\mathrm{a})$.

Ibid. at $\$ 505(\mathrm{~b})(\mathrm{ii})$.

Ibid. at $\$ 505(\mathrm{~b})(\mathrm{v})$.

Ibid. at $\$ 505(\mathrm{~b})(\mathrm{vi})$.

Supra note 6 at $\$ 8.2$.

Ibid. at $\$ 8.4(\mathrm{~A})$.

Ibid. at $\$ 8.2$. 
reinstate its rights should deter the party from "riding the well down" (that is, deliberately going into default for the purpose of delaying a commitment to participate in a well pending the outcome of tests).

The AIPNs also include an alternative provision similar to the "lien and charge" provisions of the CAPLs whereunder a lien, mortgage and security interest are granted by each party as security against default. ${ }^{69}$ In practice, this alternative remedy is rarely selected by the parties because the processes for registration and enforcement of liens, mortgages and security interests are usually difficult or non-existent in many international jurisdictions. As a general comment, the enforcement of remedies tends to be much more difficult in an international setting than a domestic one. The remedial laws of some jurisdictions may be very different from the laws of Canada and other common law jurisdictions with respect to remedies. Indeed, such laws can vary widely even among common law jurisdictions. Moreover, the enforcement of certain types of remedies (such as foreclosures and other involuntary transfers of a party's interest) will be dependent upon host government approval and the applicable law and enforcement processes (or the absence thereof) in effect in the host country.

The alternative remedy most commonly selected under the AIPNs, should the defaulting party fail to cure its default, is to require the defaulting party to transfer its interest in the operating agreement and the underlying host government contract to the other parties. ${ }^{70}$ This remedy is referred to in the international industry as "forfeiture." However, the question of the enforceability of a remedy in the nature of forfeiture is of concern. The concern relates to general legal principles holding that: provisions of agreements which amount to penalties, rather than genuine pre-estimates of damages, will not be enforced by the courts; that a court may exercise its discretion to relieve a party from forfeiture in some circumstances; and that confiscations of a person's property or contractual rights without due compensation may not be enforceable on the grounds of being contrary to public policy. I am not aware of any cases in which the forfeiture remedy under the AIPNs has been found to be in the nature of a penalty or otherwise unenforceable. Justification for upholding the forfeiture remedy in international operations has been well expressed by Andrew B. Derman:

\footnotetext{
Companies participating in the oil and gas business are generally large institutions, which are operated by sophisticated employees and advisors. Few industries assume the financial, geological and operational risk of the oil and gas industry and it does appear odd that a court would override the explicit written undertakings of such companies. Although under United States law, forfeiture is not a favored remedy, the courts examining such provisions have generally found them to be enforceable. If a non-defaulting entity is required to shoulder the financial burden for a defaulting entity, why should a court not enforce the remedy of forfeiture where it has been previously agreed to by all parties to the operating agreement? ${ }^{71}$
}

Nevertheless, due to continuing concerns about the potential lack of enforceability of the forfeiture remedy in some jurisdictions and circumstances, the 2002 version of the AIPN is likely to include additional alternative remedies, including a compulsory sale provision 
whereunder a defaulting party would be required to dispose of its interest to the nondefaulting parties for an appraised value. While a compulsory sale mechanism may appear to be an obvious and equitable alternative to forfeiture, compulsory sales raise several problems of their own, including the difficulty of determining the value of an international operation (particularly one that is in its exploration phase), and the possibility that a party which desires to avoid its commitments and sell its interest may deliberately default in order to force a buyout by the other parties.

The foregoing discussion illustrates that great care must be taken when negotiating an international operating agreement to include remedial provisions which will be enforceable (not only legally, but also practically in terms of the existence of workable enforcement processes) under the law selected as the governing law of the agreement and under the law of the host country.

\section{OWNERShIP AND Disposition OF Production}

\section{A. OIL}

Both the CAPLs and the AIPNs provide for all parties to take in kind and separately dispose of their share of production. However, in an international operation the taking and marketing of oil are usually not as straightforward as they are in onshore operations in North America. In an international oil production project, oil will often be taken by tanker vessels. The parties cannot all load their shares of production onto their respective tanker vessels at the same time. Consequently (and as a result of delays in vessel arrivals and loading schedules, variations in tanker capacity, and the availability of vessels), there will be imbalances among the parties in the taking of oil. The participants in an international oil production operation will usually enter into a lifting agreement or offtake agreement to deal with such imbalances and to establish procedures for the offtake of oil.

International operating agreements may include detailed provisions with respect to liftings or they may include only a set of general principles which will form the basis for a formal lifting agreement to be negotiated among the parties at a later time. Some international operating agreements may not address lifting arrangements at all.

In 2001, the AIPN approved a model form Lifting Procedure for use in international operations. It deals with matters such as the lifting of a single stream of crude oil production through a dedicated marine terminal, and also includes provisions to deal with the lifting of liquids other than crude oil, the lifting of a party's share of production into a non-dedicated pipeline system, and the lifting of production through one or more non-dedicated terminals. Now that the AIPN Lifting Procedure has been completed, the issue of liftings can be conveniently dealt with in an operating agreement by making reference to the model form as the basis for an eventual agreement among the parties with respect to the offtake of crude oil.

\section{B. Natural GaS}

It is not common for international operating agreements to include detailed provisions with respect to natural gas offtaking, balancing and joint marketing. In this regard, the 1995 AIPN 
model form merely states that "if natural gas is discovered it may be necessary for the Parties to enter into special arrangements for the disposal of the natural gas, which are consistent with the Development Plan and subject to the terms of the Contract." 72 This approach is based on the view that it is very difficult to anticipate and adequately prepare for the requirements of international gas balancing and marketing arrangements in advance of a discovery. However, the drafting committee of the 2002 AIPN model form has reconsidered this approach with a view to including in the model form an enumeration of some basic principles common to such arrangements which can reasonably be anticipated.

\section{DISPOSITION OF INTERESTS}

Both the CAPLs and the AIPNs contain broadly similar provisions with respect to voluntary dispositions by parties of their interests in the operating agreement and the underlying operations. For example, both model forms contain alternative provisions whereunder the parties can elect to make dispositions subject to a right of first refusal (ROFR), or subject merely to the consent of the other parties, such consent not to be unreasonably withheld. Most of the differences between the two model forms with respect to dispositions of interests result more from their separate evolution and the varying philosophies of the respective drafting committees than from any real distinctions between the domestic and international petroleum industries in this area.

There are a few noteworthy distinctions between the two model forms. For example, the ROFR provisions of the CAPLs apply only to direct transfers of an interest in the agreement and not to indirect transfers effected by way of a change in control of a participant (that is, a sale of the shares of a participant company which holds the interest in the operating agreement). Changes in control have not been included within the ambit of the ROFR provisions of the CAPLs because of a generally accepted view in the Canadian industry that large scale corporate mergers and reorganizations ought not to be impeded by restrictions in a single operating agreement. In contrast, the AIPNs' ROFR provisions purport to include not only direct transfers but also changes in control. ${ }^{73}$ Changes in control were included within the ambit of the AIPNs partly out of concern that parties might circumvent their ROFR obligations by transferring their interests to affiliated "special purpose" companies (a company incorporated for the sole or substantial purpose of holding and operating the participating interest) and then transferring control of the special purpose company to a third party. While the drafting committees of the AIPNs may not have intended the provisions to apply to large-scale corporate transactions, the provisions were drafted so broadly that one can argue that they do apply to such transactions. The 2002 version of the AIPN model form is likely to narrow the express scope of the provisions so as to clarify that they apply to changes in control of special purpose companies, but not to large-scale corporate mergers and takeovers.

As an alternative to ROFR rights, the AIPNs include an optional right of first negotiation. ${ }^{74}$ The CAPLs do not provide a similar right. Pursuant to this right, a party 
wishing to dispose of its interest in the operating agreement must first notify the other parties and invite them to submit offers for the interest. If they wish to do so, the other parties then have a specified number of days to submit a binding offer to the disposing party. The disposing party may accept one of the offers, in which case the disposing party and the prospective acquiring party have a certain number of days to negotiate in good faith and execute a definitive agreement for the transfer of the interest. If it is evident to the disposing party that the negotiation and execution of a definitive agreement with the prospective acquiring party are not imminent, or if the disposing party has rejected all of the offers submitted by the other parties, then the disposing party has the right for a certain number of months to transfer its interest to a third party on terms no more favourable to the disposing party than the best offer submitted by the other parties.

Finally, with respect to dispositions of interests in international operating agreements, it must be kept in mind that any transfer by a party of an interest in the underlying host government contract, whether to one or more of the remaining parties to the operating agreement or to a third party, will almost always require the approval of the host government under the terms of the host government contract. A failure to obtain the requisite approval of the host government will usually entitle the host government, if it should choose to do so, to terminate the host government contract.

\section{GOVERNING LAW AND DISPUTE RESOlUtion}

\section{A. GOVERNING LAW}

It is important to make a careful selection of the substantive law which will govern the interpretation, validity and enforceability of an international operating agreement. While the laws of the host country will usually govern the host government contract, the parties to the international operating agreement are free to choose the laws which will govern their relationship as set forth in the agreement.

Selecting the governing law is not an area which typically will receive or, indeed, require a great deal of attention in domestic operating agreements. The 1990 version of the CAPL model form provides that its provisions shall be construed and interpreted according to the laws of the jurisdiction within which the joint lands are situated and the federal laws of Canada applicable therein. ${ }^{75}$ In practice, it is not uncommon for the parties to choose Alberta law even when the joint lands are located outside Alberta. The head offices and primary legal advisors of many Canadian oil companies are located in Alberta, and so it is often convenient for these companies to resolve their disputes in an Alberta forum on the basis of Alberta law. Moreover, Alberta has developed an extensive and sophisticated body of oil and gas law to aid the interpretation of the operating agreement.

The AIPNs require the parties to select the governing law, ${ }^{76}$ and the choice is often the subject of considerable debate during negotiations. It is unlikely that non-Canadian participants will agree to the selection of Alberta law to govern the operating agreement. 
There are two reasons for this. First, most non-Canadian companies are unaware of the sophistication of Alberta law with respect to oil and gas matters. Second, when the parties to an international operating agreement are not all from the same jurisdiction, they will often want a "neutral" jurisdiction's laws to govern on the basis that the selection of the laws of the home jurisdiction of one of the parties may provide that party with advantages over the other parties.

I submit that, when parties choose the governing law of the operating agreement, the most important criterion is not to avoid the laws of the jurisdictions of the various parties to the agreement, but rather to choose a jurisdiction which has developed a sophisticated body of commercial law, and preferably oil and gas law. In practice, the laws of England are probably the most commonly selected in international operating agreements involving one or more non-American parties. Other laws commonly selected are those of New York and of Texas. However, increasing numbers of participants in international petroleum operations are from civil law jurisdictions and countries which adhere to Islamic or shari'a law traditions, so one may anticipate increasing pressure from such participants to adopt laws other than common law to govern the agreement.

\section{B. DisPUTE RESOLUTION}

With respect to dispute resolution, the 1995 version of the AIPN model form requires the parties to select whether disputes will be resolved by litigation in the courts of a selected jurisdiction or by an arbitration process. ${ }^{77}$ In practice, parties to an AIPN-based operating agreement will rarely select the litigation alternative. As a result, this alternative is not likely to be included in the 2002 version of the model form.

The 1990 version of the CAPL model form permits disputes over certain specific matters to be resolved by an arbitration process ${ }^{78}$ but does not provide for matters of interpretation or disputes generally to be resolved by arbitration. As alternative dispute resolution is becoming increasingly common and is of growing importance to the industry, the 2003 version of the CAPL model form will likely include a layered approach to dispute resolution to supplement the traditional litigation mechanism.

Arbitration is the most commonly selected dispute resolution process in international operating agreements. When arbitration is selected, the agreement should at a minimum provide for certain essential matters. In this regard, the AIPNs require the parties to select the number of arbitrators (either one or three), a mechanism to appoint the arbitrators in the event the parties are unable or unwilling to do so, the place of arbitration, the language of the arbitration, and the specific rules which will govern the proceedings. If it is the wish of the parties that the arbitration be administered by a recognized institution, then the rules of arbitration of the International Chamber of Commerce, the London Court of International Arbitration or the American Arbitration Association, among others, are commonly selected.

78 For example, disputes over the classification of a well (\$1010(e)); disputes regarding the approval of a facility usage fee for a production facility, the allocation of operation costs or the allocation of products utilizing a production facility $(\$ 1409)$; and disputes as to the reasonableness of an estimate of the cash value of the consideration described in a disposition notice (\$2401, Alternate $B(c)$ ). 
There are several benefits to an administered arbitration, but it can be significantly more costly than an unadministered or ad hoc arbitration. Where the parties prefer ad hoc arbitration, the arbitration rules of the United Nations Commission on International Trade Law are commonly selected.

In most cases where procedural rules are not determined by the selected arbitration rules, the procedural rules will be determined by the laws of the place of arbitration. The importance of procedural laws is often overlooked by petroleum negotiators, but such laws may have as significant an impact as substantive laws. As a result, when selecting a particular set of arbitration rules and specifying a particular place of arbitration, it is important that the parties understand the implications and effect that decision will have on the arbitration proceedings. Also, when selecting the place of arbitration, it is important to consider the question of how an arbitral award made in that place will be enforced. For example, if an international arbitral award is made in London, England, but the unsuccessful party has no valuable assets in England, how would a successful party enforce the award against the unsuccessful party if the latter does not voluntarily comply? In this regard, the negotiators of an international operating agreement need to consider whether the jurisdiction proposed as the place of arbitration (as well as the country of the petroleum operations or other jurisdictions in which the parties to the operating agreement do have valuable assets) is a signatory to a suitable international convention providing for the enforcement of international arbitral awards. The most well-known and widely ratified of such conventions is the United Nations Convention on the Recognition and Enforcement of Foreign Arbitral Awards of 1958 (the New York Convention). ${ }^{79}$

It is likely that the 2002 version of the AIPN model form will include various alternatives to arbitration, including provisions for senior executive negotiations and mediation. In this regard, the 2002 AIPN revisions committee had contemplated the possibility of making negotiations and mediation mandatory preconditions to arbitration. However, it was feared that a mandatory requirement to negotiate and mediate in advance of initiating arbitral proceedings might seriously prejudice the rights of parties in some circumstances and might be abused by parties as a tactic to stall and thereby delay the resolution of disputes. As a result, these additional alternative dispute resolution provisions will be optional.

\section{SOVEREIGN IMMUNITY}

Another issue to consider during the negotiation of an international operating agreement which would not ordinarily be necessary to consider in a domestic operation is whether any of the parties are entities which have sovereign immunity, or against which provisions of the operating agreement may be unenforceable due to their status as states or extensions of states. If so, consideration should be given to including a provision in the operating agreement whereunder such entities waive their immunity, although such a waiver may not be enforceable against the sovereign entity in all cases. The 1995 version of the AIPN model form does not contain a waiver of sovereign immunity, although a provision is likely to be included in the 2002 version of the model form. 


\section{Conclusion}

International joint operating agreements have many aspects in common with their domestic North American counterparts such as the CAPLs. However, a workable international operating agreement must address the significant distinctions between international and domestic petroleum operations. It would be a formidable task indeed to attempt to address the distinctive aspects of international operations without the aid of a model form, such as the AIPN model form International Joint Operating Agreement, which has been developed specifically for the international petroleum industry. The AIPN and CAPL model forms both have their place. The AIPN model form has been developed to reflect the petroleum standards and customs generally followed in the international industry. The CAPL model form has been developed with particular emphasis on those standards and customs of general application in the Canadian onshore industry. Each of these model forms is highly recommended as a starting point for negotiations on proposed joint petroleum operations in the specific industry for which it was developed. 